\title{
Hypocalcæmia and serum levels of inorganic phosphorus, magnesium parathyroid and calcitonin hormones in the last month of pregnancy in Awassi fat-tail ewes
}

\author{
E Elias ${ }^{1 *}, \mathrm{R}$ Shainkin-Kestenbaum 2 \\ 1 Ben Gurion University of the Negev; \\ Isan Center for Comparative Medicine and Desert Animal Research; \\ 2 Ben Gurion University of the Negev, Department of Nephrology PO Box 653, \\ Beersheva 84105 Israel
}

(Received 6 June 1990; accepted 25 September 1990)

\begin{abstract}
Summary - Serum levels of calcium $(\mathrm{Ca})$, inorganic phosphorus $(\mathrm{P})$, magnesium $(\mathrm{Mg})$, parathyroid (PTH) and calcitonin (CT) hormones of fat-tail Awassi ewes were determined during the last month of pregnancy. The incidence of hypocalcæmia (HCE) was $13.4 \%$ of the obstetrical cases examined. Twenty-six $(81.3 \%)$ of 32 ewes with HCE were 4 yr of age or older. Significant decreases $(p<0.01)$ in serum Ca levels from normal values or controls $(n=6 ; 10.04 \pm 0.22 \%(w / w))$ to pathological values $(4.30 \pm 0.35 \%(w / w))$ caused severe clinical manifestations in $75 \%$ of affected ewes. This HCE was accompanied by a significant increase in the PTH level $(142.6 \pm 9.1 \mathrm{pmol} / \mathrm{l}$ in comparison to $99.7 \pm 9.3 \mathrm{pmol} /$ in controls, $p<0.05)$ and significant decrease in serum CT level $(98.2 \pm 7.6 \mathrm{pg} / \mathrm{ml}$ in comparison to $144.6 \pm 25.7 \mathrm{pg} / \mathrm{ml}$ in controls; $p<0.05$ ). Intravenous administration of Ca borogluconate yielded normal $\mathrm{Ca}$ levels which were accompanied by a decrease in serum PTH levels and an increase in CT levels to normal values.
\end{abstract}

hypocalcæmia / phosphorus / magnesium / parathyroid hormone / calcitonin / ewe

Résumé - Hypocalcémie et niveaux plasmatiques du phosphore inorganique, du magnésium, de l'hormone parathyroïdienne et de la calcitonine pendant le dernier mois de gestation chez les brebis Awassi à queue grasse. Le niveau plasmatique du calcium (Ca), du phosphore inorganique $(P)$, du magnésium $(M g)$, de l'hormone parathyroïdienne $(P T H)$ et de la calcitonine $(C T)$ a été déterminé chez des brebis Awassi à queue grasse, pendant leur dernier mois de gestation. Le niveau d'hypocalcémie (HCE) était de $13,4 \%$ dans les cas obstétriques examinés. Vingt-six $(81,3 \%)$ des 32 brebis avec HCE étaient ágées de 4 ans ou plus. Des diminutions significatives $(P<0,01) d u$ niveau de Ca plasmatique, depuis des valeurs normales ou témoins ( $n=6 ; 100,4 \pm 2,2 \mathrm{mg} / \mathrm{l}$ ) jusqu'à des valeurs pathologiques $(43,0 \pm 3,5 \mathrm{mg} / 1)$ ont provoqué des symptômes graves chez $75 \%$ des brebis atteintes. Le HCE est accompagné d'une élévation significative du niveau de PTH $(142,6$ $\pm 9,1$ pmol//) en comparaison de 99,7 $\pm 9,3$ pmol// chez les témoins ( $P<0,05$ ), et d'une baisse significative du niveau plasmatique de CT $(98,2 \pm 7,6 \rho \mathrm{g} / \mathrm{ml})$, en comparaison du $144,6 \pm 25,7 \mathrm{pg} / \mathrm{ml}$ des témoins ( $\mathrm{P}<0,05)$. L'administration de borogluconate de calcium par voie intraveineuse a fourni des niveaux normaux de $\mathrm{Ca}$, accompagnés d'une baisse de la PTH plasmatique et d'une élévation du niveau de CT aux valeurs normales.

hypocalcémie / phosphore / magnésium / hormone parathyroïdienne / calcitonine / brebis

* Correspondence and reprints. 


\section{INTRODUCTION}

Hypocalcæmia (HCE) is a metabolic disorder which is prevalent primarily during the last 6 weeks of pregnancy in the ewe (Jensen, 1974; Allen and Sansom, 1986). HCE probably occurs in all major sheepproducing countries, including Germany (Bostedt and Hausmann, 1980), Scandinavia (Mosdol and Waage, 1981), the UK (Kemp et al, 1985), Australia (Larsen et al, 1986) and Egypt (lbrahim et al, 1986). HCE was first reported in Awassi ewes in Israel by Egyed and de Lange (1967).

Late pregnancy is accompanied by changes in the serum concentrations of several hormones. Popoff (1982) and Matsui et al (1983) found a relationship between hyperparathyroidism and HCE in sheep. Similarly during parturient paresis (milk fever) in the cow, parathyroid hormone (PTH) concentration is higher (Horst et al, 1978; Allen and Sansom, 1986; Bar et al, 1988) and calcitonin (CT) concentration is lower (Mayer et al, 1975; Allen and Sansom, 1986) than normal values.

The purpose of the present study was to examine the relationship between changes in calcium (Ca) and calciumregulating hormones (PTH and $C T$ ) in the last 3-4 wk of pregnancy in Awassi fat-tail ewes with HCE and the effect of $\mathrm{Ca}$ administration on hormone levels.

\section{MATERIALS AND METHODS}

The study was conducted over a 2-yr period from November 1987 to January 1990.

\section{Animals}

Thirty-two Awassi fat-tail pregnant ewes with signs of HCE were selected from 238 obstetrical cases examined at the clinical services of the Isan Center for Comparative Medicine of Ben Gurion University of the Negev. Ewes ranged in age from 2-7 yr and were from Bedouin flocks. Six Awassi fat-tail pregnant ewes in their last month of pregnancy and also taken from Bedouin flocks were used as controls. These ewes were in good health and ranged in age from 2-6 yr. According to the owners, all sheep were fed stale bread, barley, bran, sometimes oats, and straw ad libitum.

\section{Clinical examination}

Pregnancy was determined by abdominal palpation (last month of pregnancy). Each ewe was examined physically by routine procedures.

Differential diagnosis included pregnancy toxæmia, hypomagnesæmia and enterotoxæmia. Differential diagnosis from ovine pregnancy toxæmia was based on the feeding and management history of the flock (owners' reports), blood glucose concentrations determined by Dextrostix test strips (Miles Laboratories, France) and response to treatment for HCE (Marteniuk and Herdt, 1988). Analysis of serum Ca values was used for confirmation of HCE diagnosis.

\section{Treatment of HCE ewes}

Each ewe with HCE (below $9 \%$ (w/w) by NRC, 1985) was treated by intravenous infusion of $30-100 \mathrm{ml}$ of $\mathrm{Ca}$ borogluconate $20 \%$ solution. Infusion took between 4.5-6.5 min. Ewes $(n=8)$ with a moderately depressed level of serum $\mathrm{Ca}$ $(6.5-8.9 \%(w / w))$ were given $30-50 \mathrm{ml}$ of infusion, whereas ewes $(n=24)$ with a strongly depressed level of serum Ca (below $4.5 \%(w / w)$ ) were given $60-100 \mathrm{ml} \mathrm{Ca}$ borogluconate. After $20 \mathrm{~min}$ all treated ewes received $120 \mathrm{ml} \mathrm{Ca}$ borogluconate solution subcutaneously.

\section{Blood samples}

Blood (10 ml) was taken from the jugular vein into Vacutainer tubes and was centrifuged im- 
mediately at $3000 \mathrm{rpm}$ for $15 \mathrm{~min}$. Blood was collected from each ewe immediately after physical examination and 20 min after treatment with Ca borogluconate $20 \%$ solution injected intravenously. All samples were stored at $-20^{\circ} \mathrm{C}$ until assayed for PTH and CT.

\section{Biochemical analysis}

Serum $\mathrm{Ca}$, inorganic phosphorus $(P)$ and magnesium $(\mathrm{Mg})$ were measured with Poli-Mak $\mathrm{M}_{10}$ analyser (Poli-Mak, Italy) using a commercial test kit (Bio Merieux).

\section{Hormone assay procedures}

Hormone levels were tested in 15 randomly chosen HCE ewes and 6 controls. PTH levels were determined by RIA using an Incstar Corporation kit (Stillwater, MN 55082, USA) for midmolecule, using iodinated PTH mid-molecule (44-68 amino acid) as a tracer and antibody sensitive to this region of the PTH molecule. The minimum sensitivity, intraassay and interassay cœefficients of variation were $10 \mathrm{pmol} / \mathrm{h} \%$ and $10 \%$, respectively. Results are expressed in pmol/.

CT concentrations were determined by RIA using DPC kit (Diagnostic Product Corporation, 5700 West 96th St, Los Angeles, CA 90045, USA). The minimum sensitivity, intraassay and interassay coefficients of variation were $16 \mathrm{pg} /$ $\mathrm{ml}, 5 \%$ and $8 \%$, respectively. Results are expressed in $\mathrm{pg} / \mathrm{ml}$.

\section{Statistical analysis}

All statistical methods were according to Sokal and Rohlf (1973). Differences between serum values of $\mathrm{Ca}, \mathrm{P}, \mathrm{Mg}, \mathrm{PTH}$ and $\mathrm{CT}$ before and after treatment were evaluated statistically using Student's $t$-test. A level of $p<0.05$ was chosen as significant. Results are expressed as means ( \pm SEM).

\section{RESULTS}

The incidence of HCE during the last month of pregnancy in Awassi fat-tail ewes was $13.4 \%$ of obstetrical cases examined. From a total of 32 cases, HCE occurred in $17(53.1 \%)$ ewes over $4 \mathrm{yr}$; in $9(28.1 \%)$ $4 \mathrm{yr}$ old ewes and in $6(18.7 \%)$ under $4 \mathrm{yr}$. Eleven (34.3\%) of the 32 ewes with HCE carried twins. Cases of HCE were first observed in early November and reached a peak in December-January, which is the main lambing season.

\section{Clinical signs}

All ewes with HCE were in the last month of pregnancy. Muscle tremors, particularly of the head and limbs, and forward head extension were common signs of HCE. Constipation was evident and tympanitic rumen developed in $14(43.7 \%)$ of the 32 cases. Heart rate was decreased and respiration was shallow and slow in all examined cases. After intravenous infusion, the ewes were able to stand in $4.2 \pm 0.02 \mathrm{~min}$ and always urinated and defæcated (usually dry fæces) after 5-8 min following treatment.

\section{Biochemical data}

The serum concentration of Ca decreased in all examined ewes to $4.30 \pm 0.35 \%(w / w)$ (table I). Ca levels ranged between $2.8 \%$ $(w / w)$ and $4.8 \%(w / w)$ in ewes with twins. In $24(75 \%)$ cases the level of $\mathrm{Ca}$ was $<4.5 \%(\mathrm{w} / \mathrm{w})$. The serum $\mathrm{P}$ and $\mathrm{Mg}$ values did not change in HCE ewes (table I). 
Table I. Serum levels of calcium $(\mathrm{Ca})$, inorganic phosphorus $(\mathrm{P})$, magnesium $(\mathrm{Mg})$, parathyroid hormone (PTH) and calcitonin (CT) before and after treatment.

\begin{tabular}{|c|c|c|c|c|}
\hline \multirow[b]{2}{*}{ Item } & \multicolumn{3}{|c|}{ Serum level } & \multirow[b]{2}{*}{$\begin{array}{l}\text { Reference range } \\
\text { (Hoffman, 1986) }\end{array}$} \\
\hline & Control & $\begin{array}{l}\text { Before } \\
\text { treatment }\end{array}$ & $\begin{array}{c}\text { After } \\
\text { treatment* }\end{array}$ & \\
\hline $\begin{array}{l}\text { No of } \\
\text { ewes }\end{array}$ & 6 & 32 & 32 & - \\
\hline $\begin{array}{l}\mathrm{Ca}(\mathrm{mg} \%) \\
\mathrm{P}(\mathrm{mg} \%) \\
\mathrm{Mg}(\mathrm{mg} \%)\end{array}$ & $\begin{array}{c}10.4 \pm 0.22^{a} \\
4.30 \pm 0.40^{a} \\
2.81 \pm 0.15\end{array}$ & $\begin{array}{c}4.30 \pm 0.35^{\mathrm{b}} \\
5.61 \pm 0.32^{\mathrm{ab}} \\
3.01 \pm 0.23\end{array}$ & $\begin{array}{c}12.89 \pm 1.16^{\mathrm{a}} \\
6.19 \pm 0.30^{\mathrm{b}} \\
3.59 \pm 0.26\end{array}$ & $\begin{array}{c}12.16 \pm 0.28 \\
5.20 \pm 0.11 \\
2.50 \pm 0.30\end{array}$ \\
\hline $\begin{array}{l}\text { No of } \\
\text { ewes }\end{array}$ & 6 & 15 & 15 & - \\
\hline $\begin{array}{l}\text { PTH }(\mathrm{pmol} / \mathrm{l}) \\
\text { CT }(\mathrm{pg} / \mathrm{ml})\end{array}$ & $\begin{array}{c}99.7 \pm 9.32^{\mathrm{a}} \\
144.6 \pm 25.7^{\mathrm{a}}\end{array}$ & $\begin{array}{c}142.6 \pm 9.1^{b} \\
98.2 \pm 7.6^{b}\end{array}$ & $\begin{array}{c}100.7 \pm 8.4^{a} \\
117.6 \pm 10.9^{a b}\end{array}$ & \\
\hline
\end{tabular}

* Twenty min after intravenous injection of calcium borogluconate $20 \%$ solution. Means with different superscripts are significantly different from each other $(P<0.05)$; data are expressed as mean \pm SEM.

Twenty min after treatment the serum level of $\mathrm{Ca}$ increased to $12.89 \pm 1.16 \%(\mathrm{w} / \mathrm{w})$ and $P$ levels also increased compared to controls or reference normals (table I). The level of $\mathrm{Mg}$ was unchanged before and after $\mathrm{Ca}$ infusion. Blood glucose measurements performed with a strip test showed values of $90 \%(w / w)$ in all examined cases including 6 control ewes.

\section{Differential diagnosis}

HCE may clinically mimic pregnancy toxæmia, but normal blood glucose levels, Ca levels of below $5 \%$ (table I) and rapid response to treatment with calcium borogluconate confirmed the diagnosis of HCE.

\section{Hormonal changes}

PTH increased significantly $(P<0.01)$ in all 15 cases of HCE. After $\mathrm{Ca}$ administration PTH decreased from $142.6 \pm 9.1 \mathrm{\rho mol} / \mathrm{l}$ before treatment to $100.7 \pm 8.4 \mathrm{\rho mol} / \mathrm{l}$ (table 1). The serum concentration of PTH rose in conjunction with the sharp decline in the levels of serum Ca. Serum levels of CT were significantly decreased $(P<0.02)$ before treatment and increased to normal levels (as controls) after $\mathrm{Ca}$ infusion (table I).

\section{DISCUSSION}

In pregnant ewes there is a mild decrease in $\mathrm{Ca}$ levels in the last 6 wk of pregnancy, 
but not below 9\% (w/w) (NRC, 1985; Allen and Sansom, 1986). Severe clinical signs of HCE occurred in pregnant ewes when the level of serum Ca was equal to or below $4.5 \%(w / w)$. Serum Ca concentration is usually below $6 \%(w / w)$ in cases of primary HCE (Materniuk and Herdt, 1988), in agreement with the results of this study. The rtiology of the disease is not really understood, but the condition seems to arise because of increased fotal calcium requirements coupled with factors limiting Ca supply (Ibrahim et al, 1986; Farningham, 1988). In the present study it was concluded that poor nutrition ( $\mathrm{Ca}$ deficient diets) in the last month of pregnancy caused severe HCE in $75 \%$ of examined cases (more marked in twins). It has been reported that sheep may respond to low $\mathrm{Ca}$ diets with a reduction in serum $\mathrm{Ca}$ and a gradual depletion of skeletal reserves (Fontenot and Church, 1979; NRC, 1985). In late pregnancy, the ewe is dependent on a constant daily intake of $\mathrm{Ca}$ because of the continual loss of $\mathrm{Ca}$ to the fotus, probably aggravated by the presence of more than one fœetus. Resorption of skeletal reserves proceeds at a maximum rate in ewes for 3 wk before and after lambing (Larsen et al, 1986). The amount of $\mathrm{Ca}$ absorbed from the intestine increases steadily during pregnancy in the ewes and reaches a peak in late lactation and then slowly declines (Braithwaite, 1983a). Changes in bone stores occur in late pregnancy as a result of changes in $\mathrm{Ca}$ requirements rather than in $P$ requirements, and accretion of $P$ into bone or resorption of $P$ from bone occurs merely as a consequence of this change in $\mathrm{Ca}$ requirements (Braithwaite, 1983b). It is known that wheat bread, barley and bran contain large quantities of $P$. The excess of $P$ in the diet might be a significant factor in depressing $\mathrm{Ca}$ absorption and plasma $\mathrm{Ca}$, thus leading to hyperparathyroidism (Farningham, 1988). High levels of $P$ also have been shown to increase the incidence of HCE in the cow (Goff et al, 1987). We found no difference in serum $P$ in HCE affected pregnant ewes. However, in horses (Krook, 1968) and rats (Draper et al, 1972) consumption of diets high in $P$ has been shown to induce a rise in plasma $\mathrm{P}, \mathrm{a}$ decrease in plasma $\mathrm{Ca}$ and a stimulation of PTH synthesis. Cereal grain alone cannot provide sufficient $\mathrm{Ca}$ to fulfill requirements in sheep (ARC, 1980). However, long-term $\mathrm{Ca}$ deficiency was reflected in reduced serum levels in affected ewes. The significant decrease $(P<0.01)$ of serum $\mathrm{Ca}$ concentrations from normal or control values (table I) to pathological values undoubtedly caused clinical manifestations of HCE. Ewes of over $4 \mathrm{yr}$ old were usually more severely affected. The same was true for Awassi ewes with HCE reported 2-3 mo after lambing, where the average age of clinically affected animals was 5.3 yr (Egyed and de Lange, 1967).

It has been reported that HCE will decrease ruminal and abomasal mobility in sheep by decreasing the contraction of smooth muscle (Huber et al, 1981). This can explain the tympanitic rumen, the constipation and dry fæces in examined ewes with HCE.

Normal values of blood glucose corroborated with $\mathrm{Ca}$ levels below $6 \%(\mathrm{w} / \mathrm{w})$ and rapid response to treatment with $\mathrm{Ca}$ borogluconate in all the pregnant ewes examined excluded possible presumptive diagnosis of pregnancy toxæmia where glucose values are depressed, as a rule by $20-40 \%$ (w/w) (Materniuk and Herdt, 1988).

Regulation of $\mathrm{Ca}, \mathrm{P}$ and $\mathrm{Mg}$ pools is controlled by PTH, CT and vitamin D derivatives (Goff et al, 1987; Reinhardt et al, 1988). Severe HCE in Awassi pregnant ewes induced secretion of PTH, as in the cow (Bar et al, 1988) and a decline in CT. Treatment with $\mathrm{Ca}$ borogluconate resulted in normal $\mathrm{Ca}$ levels, and both hormone lev- 
els returned to normal after 20 min (mean CT level did not differ significantly from normal).

Infusion of $\mathrm{Ca}$ directly into the blood in HCE ewes also increased $P$ levels compared to control or normal levels (table I). A previous study (Braithwaite, 1978) has shown that with direct infusion of $\mathrm{Ca}$ into the blood, much of the infused $\mathrm{Ca}$ is retained irrespective of the animals' needs and that the increased $\mathrm{Ca}$ retention is accompanied by an increased $P$ retention. Hypothetically it may be presumed that as the intravenous $\mathrm{Ca}$ infusion depressed the levels of PTH which is a phosphaturic hormone and the kidney function was normal, the PTH depression may have led to retention of $P$ and raised serum $P$ level 20 min after $\mathrm{Ca}$ infusion.

The accepted standard treatment of HCE in animals is the intravenous administration of $\mathrm{Ca}$. There is a good correlation between clinical signs and serum $\mathrm{Ca}$ levels, allowing clinical judgment to be made of the severity of HCE. It is reasonable to assume that different degrees of HCE in ewes require different levels of $\mathrm{Ca}$, as in the cow (Kvart and Larsson, 1987). The use of the same dose of $\mathrm{Ca}$ borogluconate in all affected ewes can result in severe cardiac arrythmias and death. Severe HCE (by Ca serum level) in Awassi pregnant ewes should be treated with 80-100 $\mathrm{ml} \mathrm{Ca}$ borogluconate $20 \%$ IV solution; for ewes with moderate HCE, $30-40 \mathrm{ml}$ is sufficient.

In conclusion, during late pregnancy, due to excessive fœtal $\mathrm{Ca}$ requirements, Ca deficient diets lead to HCE and changes in $\mathrm{Ca}$ regulating hormones (more PTH and less CT). Intravenous administration of $\mathrm{Ca}$ re-establishes normal $\mathrm{Ca}$ values and is accompanied by a return to normal PTH and CT levels after $20 \mathrm{~min}$.

\section{ACKNOWLEDGMENTS}

The authors are grateful to Ms Gisella Tamir for technical assistance and Ms Myra Bennett for assistance in the preparation and typing of the manuscript.

\section{REFERENCES}

Allen WM, Sansom BF (1986) Metabolic disorders. In: Current Veterinary Therapy; Food Animal Practice 2 (Howard JL, ed) WB Saunders $\mathrm{Co}$, Philadelphia, 311-322

ARC (Agricultural Research Council) (1980) The Nutrient Requirements of Ruminant Livestock. Commonw Agric Bur, London

Bar A, Striem S, Perlman R, Sachs M (1988) Use of $1 \alpha$-hydroxyvitamin $D_{3}$ in prevention of bovine parturient paresis. VIII. Maternal and neonatal plasma calcium, parathyroid hormone and vitamin D metabolite concentrations. J Dairy Sci 71, 2723-2729

Bostedt H, Hausmann C (1980) Influence of advanced pregnancy, parturition and early lactation on the electrolyte concentrations in plasma of sheep, with special regard to paresis before lambing. Prakt Tierarzt 61, 482 . 489

Braithwaite GD (1978) Adaptations in the calcium and phosphorus metabolism of sheep in response to an intravenous infusion of $\mathrm{Ca}$. Br J Nutr 40, 17-21

Braithwaite GD (1983a) Calcium and phosphorus requirements of the ewe during pregnancy and lactation. I. Calcium. Br J Nutr 50, 711722

Braithwaite GD (1983b) Calcium and phosphorus requirements of the ewe during pregnancy and lactation. II. Phosphorus. Br J Nutr 50, 723-736

Draper HH, Sie TL, Bergan JG (1972) Osteoporosis in aging rats induced by high phosphorus diets. J Nutr 102, 1133-1142

Egyed M, de Lange A (1967) Hypocalcæmia and hypomagnesæmia in lactating Awassi ewes. Ref Vet 24, 34-36 
Farningham DAH (1988) Hypocalcomia in the ewe. Vet Annu 28, 74-77

Fontenot JP, Church DC (1979) Digestive Physiology and Nutrition of Ruminants; The Macro (Major) Minerals, Vol 2: Nutrition (Church DC, ed) Oxford Press, OR, 2nd edn 56-93

Goff JP, Horst RL, Reinhardt TA (1987) The pathophysiology and prevention of milk fever. Vet Med 82, 943-950

Hoffmann WE (1986) Partial list of normal values, appendix 961. In: Current Veterinary Therapy. Food Animal Practice 2 (Howard JL, ed) WB Saunders Co, Philadelphia, 961

Horst RL, Jorgensen NA, de Luca HF (1978) Plasma 1,25 dihydroxy vitamin $D$ and parathyroid hormone levels in paretic dairy cows. Am J Physiol 35, E634-E637

Huber TL, Wilson RC, Stattelman AJ, Goetsch DD (1981) Effect of hypocalcæmia on the motility of the ruminant stomach. Am J Vet Res 42, 1488-1490

Ibrahim $H$, Serur B, Gomaa A, Farrage A, Allam $F$ (1986) Blood serum calcium, inorganic phosphorus and magnesium of ewes at prepartal and postpartal periods. Assiut Vet Med $J 17,115-119$

Jensen $R$ (1974) Diseases of Sheep (R Jensen, ed) Lea \& Febiger, Philadelphia, 23-30

Kemp J, Mansbridge R, Wilson GDA (1985) Hypocalcæmia in ewes. Vet Rec 117, 450

Krook L (1968) Dietary calcium-phosphorus and lameness in the horse. Cornell Vet (suppl 1), $58,59-73$
Kvart C, Larsson L (1967) An alternative regimen for calcium treatment of parturient paresis based on clinical signs. $J$ Vet Med A 34, 684-689

Larsen JWA, Constable PD, Napthine DV (1986) Hypocalcæmia in ewes after a drought. Aust Vet J 63, 25-26

Marteniuk JV, Herdt TH (1988) Pregnancy toxæmia and ketosis of ewes and does. Vet Clin North Am 4, 307-315

Matsui T, Yano H, Kawashima R (1983) Effect of calcitonin and parathyroid hormone deficiency on calcium and phosphorus metabolism in sheep. Jpn J Zootech Sci 54, 232-238

Mayer GP, Blum JW, Deftos LJ (1975) Diminished prepartal plasma calcitonin concentration in cows developing parturient hypocalcæmia. Endocrinology 96, 1478-1485

Mosdol G, Waage S (1981) Hypocalcæmia in the ewe. Nord Veterinaermed 33, 310-326

NRC (1985) Nutrient Requirements of Sheep. Natl Acad Press, Washington, USA, 6th revised edn, 11-14

Popoff M (1982) Harmful effects of a diet rich in grain on the phosphorus and calcium metabolism of sheep. Bull Mens Soc Vet Prat Fr $66,357-360,362-366$

Reinhardt TA, Horst RL, Goff JP (1988) Calcium, phosphorus, and magnesium homeostasis in ruminants. Vet Clin North Am 4 , 331-349

Sokal RR, Rohlf FJ (1973) Introduction to Biostatistics. WH Freeman and Co, San Francisco, 170-173 